\title{
Using computers to take patient histories
}

\author{
Accurate and acceptable to patients
}

The inadequacies of manual record systems, the inconsistencies in applying increasingly complex medical information, ${ }^{1}$ and a need for efficient allocation of time have created an interest in computerised history taking. Before such histories become widely accepted, however, doctors need to be clear about their indications, efficacy, and possible difficulties.

The indications for computerising all or part of the patient history are to prepare the doctor, ${ }^{2-11}$ give advice on lifestyle, ${ }^{12-17}$ improve compliance with protocols, ${ }^{18}$ offer diagnostic support for doctors, ${ }^{19-24}$ and help non-medical staff to make diagnoses. ${ }^{25} 26$ Such histories may be entered directly by the patients themselves ${ }^{3-16}$ or by an intermediary who may be a clerical assistant, ${ }^{172526}$ a health professional, ${ }^{2}$ or a doctor. ${ }^{18-24}$ The history may either concentrate on limited topics, such as abdominal symptoms ${ }^{19} 2023-25$ and the state of health, ${ }^{32-17}$ or may attempt to be eclectic. ${ }^{579-1126}$

Computer histories are more exhaustive than those taken in the normal way. Information may increase by half, ${ }^{70}$ and factual "discoveries" have been increased by an average of $5 \cdot 4^{8}$ and $16^{2}$ new items for each patient. Such gains may take a long time to achieve. ${ }^{5711}$ Some studies show an increased disclosure of sensitive information such as alcohol consumption to a computer, ${ }^{87-29}$ but this is not always the case $\mathrm{e}^{12}$; the increased disclosure may result solely because the computer is willing to ask questions that doctors prefer to avoid.

Computerised patient histories may increase the diagnostic certainty. ${ }^{79.22} 25$ For example, one system for diagnosing abdominal pain has been claimed to offer savings of $£ 23 \mathrm{~m}$ a year to the National Health Service through avoided operations and nights in hospital, ${ }^{19}$ while another could reduce admissions to coronary care units by a sixth. ${ }^{22}$ These gains occur particularly. with narrow topics ${ }^{30-35}$; if the net is dragged too wide the diagnostic accuracy drops. ${ }^{10} 35$

Some possible difficulties need to be considered. If doctors use computers themselves either to enter or to review patient histories there might be an adverse effect on their consultations. The results of studies on the use of computers by general practitioners during consultations have, however, been broadly reassuring, ${ }^{36-41}$ although the studies did not look at history taking itself. The use of computer terminals during consultations still occurs in only $12 \%$ of general practices, ${ }^{42}$ but this will greatly increase with the new free computer systems,${ }^{43}$ one of which will offer a module for history taking. ${ }^{9}$ If most of the use occurs before rather than during the consultation any adverse effects on the consultation should be mitigated.

Patients generally have a positive attitude to using computers in health care, ${ }^{44-46}$ and this remains positive after they have given their history to a computer. $.^{2-68} 813-152734374748$ In one study only $13 \%$ of patients expressed a preference for a computer history before they had given their history to a computer, but this rose to $43 \%$ afterwards. ${ }^{12}$

Some rules for taking histories by computer have recently been proposed by Brownbridge et al. ${ }^{49}$ The time taken to complete a computer questionnaire varies according to age and education, ${ }^{50}$ and this should be taken into account in designing systems for use by patients. The system users need to be closely consulted, and any effects, particularly on the time spent by staff and patients, ${ }^{25}$ should be carefully considered.

The computer history should be an adjunct to not a substitute for the conventional medical interview. ${ }^{72} 2931$ Computer histories may miss important information by relying on closed structured questions; they miss non-verbal clues; and they are impersonal. The use of computers during the consultation should be carefully managed to minimise interference with rapport. If used for diagnostic support the computer should be used in well defined and systematically evaluated clinical topics. ${ }^{27-31}$

Early visions of computers replacing doctors are now seen as misplaced, although doctors may still see computers that help with diagnosis as competitors. ${ }^{3151}$ Computers may, however, be used acceptably to gather accurate information and to improve medical decisions without diminishing the role of the doctor. A computer should "do for the doctor what a well designed golf course does for the golfer. It should flatter his strengths, reward his good efforts, and-instead of harshly punishing his errors - so motivate him that he seeks to improve his own performance." ${ }_{22}$ Computerised history taking may do just that if doctors will allow it.

Senior Lecturer,

MIKE PRINGLE

Department of General Practice,

Nottingham University Medical School,

Nottingham NH7 2UH

1 Young DW. A survey of decision aids for clinicians. Br Med f 1982;285:1332-6.

2 Lilford RJ, Bingham P, Fawdry R, Setchell M, Chard T. The development of on-line history taking systems in antenatal care. Methods Inf Med 1983;22:189-97.

White DH. The computer health check—the first 100 patients. 7 R Coll Gen Pract 1984;34:661-3.

4 Lilford RJ, Glyn-Evans D, Chard T. The use of a patient-interactive microcomputer system to obtain histories in an infertility and gynecologic endocrinology clinic. Am $\mathcal{F}$ Obstet Gynecol 1983;146:374-9.

5 Dove GAW, Wigg P, Clarke JHC, et al. The therapeutic effect of taking a patient's history by computer. I R Coll Gen Pract 1977;27:477-81. 
6 Millstein SG, Irwin CE. Acceptability of computer-acquired sexual histories in adolescent girls. 7 Pediatr 1983;103:815-9.

Quaak MJ, Westerman RF, Schouten JA, Hasman A, van Bemmel JH. Computerization of the patient history-patient answers compared with medical records. Methods Inf Med 1986;25: $222-8$

8 Carr AC, Ghosh A, Ancill RJ. Can a computer take a psychiatric history? Psychol Med 1983; 13:151-8

9 Somerville S, Evans CR, Pobgee PJ, Bevan NS. MiCKIE-experiences in taking histories from patients using a microprocessor. In: Barber B, ed. Medical Informatics Europe-proceedings. Munich: Springer, 1979:713-21.

10 Quaak MJ, Westerman RF, van Bemmel JH. Comparisons between written and computerised patient histories. Br Med f 1987;295:184-90.

11 Haug PJ, Warner HR, Clayton PD, et al. A decision-driven system to collect the patient history. Compu Biomed Res 1987:20:193-207.

12 Skinner HA, Allen BA, McIntosh MC, Palmer WH. Lifestyle assessment: applying microcomputers in family practice. Br Med f 1985;290:212-6.

13 Chen MS, Houston TP, Burson JL, Comer RC. Microcomputer-based patient education programs for family practice. 7 Fam Pract 1984;18:149-50.

14 Ellis LBM, Raines JR. Health education using microcomputers. Prev Med 1981;10:77-84

15 Ellis LBM, Raines JR, Hakanson N. Health education using microcomputers. Prev Med $1982 ; 11: 212-24$

16 Trell $\mathrm{E}$. Interactive computer program for self-distributed medical questionnaires. Med Inf(Lond) $1983 ; 8: 139-43$

17 Rowe I, Boss P, Baxter R. Evaluation of automated health testing at the Shepherd Foundation. Aus Fam Physician 1984;13:742-6.

18 Brownbridge G, Evans A, Fitter $M$, Platts $M$. An interactive computerized protocol for the management of hypertension: effects on the general practitioner's clinical behaviour. $f R$ Coll Gen Pract 1986;286: 198-202.

19 Adams ID, Chan M, Clifford PC, et al. Computer aided diagnosis of acute abdominal pain: a multicentre study. Br.Med J 1986;293:800-4.

20 Wilson PD, Horrocks JC, Lyndon PJ, Yeung CK, Page RE, De Dombal FT. Simplified computeraided diagnosis of acute abdominal pain. Br.Med f 1975;ii:73-5.

21 Ross DJ, Large DF, Smith ME. A microcomputer hand injury recording system. 7 Hand Surg $[\mathrm{Br}]$ 1985;10:308-10.

22 Pozen MW, D'Agostino RB, Selker HP, Sytkowski PA, Hood WB. A predictive instrument to improve coronary-care-unit admission practices in acute ischemic heart disease. $N$ Engl f Med 1984;310:1273-8.

23 Dunwoodic WM. Computer-aided diagnosis in dyspepsia. Practitioner 1987;231:162-8.

24 Barber DC, Fox J. FIRST AID: a design philosophy and a program for on-line symptom processing. Int $\mathcal{A}$ Biomed Comput 1981;18:249-65.

25 Lawrence PC, Clifford PC, Taylor IF. Acute abdominal pain: computer aided diagnosis by non medically qualified staff. Ann $R$ Coll Surg Engl 1987;69:233-4.

26 Osborne SF. Medical diagnosis aboard submarines. 7 Occup Med 1984;26:110-4

27 Lucas RW, Mullin PJ, Luna CBX, McInroy DC. Psychiatrists and a computer as interrogators of patients with alcohol-related illnesses: a comparison. Br 7 Psychiatry 1977;131:160-7.

28 Slack WV, Slack CW. Patient-computer dialogue. N Engl f Med 1972;286:1304-9.

29 Anonymous. Psychological assessment by computer [Editorial]. Lancet 1983;i:1023-4.
30 Knill-Jones RP, Dunwoodie WM, Crean GP. A computer-assisted diagnostic decision system for dyspepsia. In: Sheldon M, Brooke J, Rector A, eds. Decision-making in general practice. Basingstoke: Macmillan, 1985:203-19.

31 Johnson R. Artificial intelligence and expert systems. In: Sheldon $M$, Stoddart N, eds. Trends in general practice computing. London: Royal College of General Practitioners, 1985:199-204.

2 Dunwoodie WM. Diagnostic systems. In: Sheldon M, Stoddart N, eds. Trends in general practice computing. London: Royal College of General Practitioners, 1985:205-11.

33 Lilford RJ. Comparisons between written and computerised patient histories. Br Med $\mathrm{f}$ 1987;295:503

34 Houziaux M-O, Lefenvre PJ. Historical and methodological aspects of computer-assisted medical history-taking. Med Inf (Lond) 1986;11:129-43.

35 Quaak MJ, Westerman RF, Schouten JA, Hasman A, van Bemmel JH. Appraisal of computerized medical histories: comparisons between computerized and conventional records. Comput Biomed Res 1986:19:551-64.

36 Herzmark G, Brownbridge G, Fitter M, Evans A. Consultation use of a computer by general practitioners. F $R$ Coll Gen Pract 1984;269:649-54.

37 Pringle M, Robins S, Brown G. Computer assisted screening: effect on the patient and the consultation. BrMed f 1985;290:1709-12.

8 Pringle $M$, Robins S, Brown G. Topic analysis: an objective measure of the consultation and its application to computer assisted consultations. $\mathrm{BrMed} \mathcal{F}$ 1985;290:1789-91.

9 Pringle M, Robins S, Brown G. TIMER: a new objective measure of the consultation and its application to computer assisted consultations. Br Med f 1986;293:20-2.

40 Brownbridge G, Herzmark GA, Wall TD. Patient reactions to doctors' computer use in general practice consultations. Soc Sci Med 1985;20:47-52.

41 Fitter M. Evaluation of computers in primary health care: the effect on doctor-patient communication. In: Peterson HE, Schneider W, eds. Human-computer communications in health care. North Holland: Elsevier Science, 1986:67-80.

42 NHS Information Technology Branch. Survey of computerised general practices. London: Department of Health and Social Security, 1987.

43 Pringle M. Greeks bearing gifts. BrMed f 1987;295:738-9.

44 Cruickshank PJ. Computers in medicine: patients' attitudes. $f R$ Coll Gen Pract 1984;34:77-80.

45 Lamey PJ, Webster G. Computers in the dental surgery: the patients' views. Br Dent $\mathcal{f}$ 1985; 159:161-2.

46 Pringle M, Robins S, Brown G. Computers in the surgery: the patients' view. Br Med $\mathcal{F}$ 1984;288: 289-91.

47 Slack W, Porter D, Witschi J, Sullivan M, Buxbaum R, Stare FJ. Dietary interviewing by computer. I Am Diet Assoc 1976;69:514-7.

48 Lilford RJ, Chard T. Microcomputers in antenatal care: a feasibility study on the booking interview. BrMed $\mathcal{F}$ 1981;283:533-6.

49 Brownbridge G, Lilford R, Tyndale-Biscoe $S$. Use of a computer to take booking histories in a hospital antenatal clinic: acceptability to midwives and patients and effects on the midwifepatient interaction. Medical Care 1988;26:474-87.

50 Coombs GJ, Murray WR, Krahn DW. Automated medical histories: factors determining patient performance. Comput Biomed Res 1970:3:178-81.

51 Grossman JH, Barnett GO, McGuire MT, Swedlow DB. Evaluation of computer-acquired patient histories. FAMA 1971;215:1286-91.

52 de Dombal FT. Computers and the surgeon-a matter of decision. Surg Annu 1979;11:33-57.

\section{Treating the ascites of cirrhosis}

\section{Diuretics are usually better than paracentesis}

Paracentesis was abandoned as treatment for tense ascites in the 1950s. This was because of the arrival of effective diuretic drugs and concern over the complication of abdominal paracentesis, particularly sepsis, hypotension, encephalopathy, and electrolyte derangement. ${ }^{12}$ The haemodynamic and electrolyte abnormalities were attributed to hypovolaemia caused by the rapid reaccumulation of fluid within the abdominal cavity. Treatment with diuretics may also cause complications-encephalopathy, hyponatraemia, hypotension, and uraemia. The high frequency of these complications reported in earlier studies ${ }^{34}$ has, however, been greatly reduced by paying close attention to electrolyte concentrations and using distally acting diuretics such as spironolactone rather than loop diuretics such as frusemide. ${ }^{56}$ Limiting the rate of diuresis to a weight loss of not more than $0.5 \mathrm{~kg}$ daily is particularly important in preventing complications. ${ }^{4-9}$ This means, however, that symptomatic relief is often delayed and the period of immobility increased compared with paracentesis, which has led to the reconsideration of paracentesis as a form of treatment.

The renewed interest in paracentesis stems from the work of Quintero et al from Barcelona. ${ }^{10}$ In 1985 they reported the results of a randomised controlled trial in which a daily 5-6 litre paracentesis together with an infusion of $40 \mathrm{~g}$ albumin was compared with treatment with diuretic drugs (spironolactone 200-400 mg and frusemide 40-240 mg daily). Ascites was controlled completely in all of the patients treated by paracentesis but in only 28 of the 34 treated with diuretics. Mean weight loss was the same in both groups, but the stay in hospital was 12 days for those having repeated paracentesis and 34 days for those given diuretics. Important complications (hypotension, renal failure, hyponatraemia, and encephalopathy) were observed in 15 of those given diuretics and nine of those treated with paracentesis. This difference was not significant, and there was no difference in rates of readmission and in mortality after 21 weeks. Complications were seen more often in those treated with diuretics in this study than would be expected from previous studies, ${ }^{56}$ and this may be explained by the high doses of diuretics used. In a previous study from the same centre lower doses were used (frusemide $160 \mathrm{mg}$ and spironolactone $300 \mathrm{mg}$ ), with fewer complications (five out of 40 patients), and yet only two patients failed to respond. ${ }^{5}$

Kao et al examined the effects of large volume (5 litre) paracentesis without replacement of albumin in 18 patients with tense ascites and peripheral oedema, and the only complication was leakage from paracentesis sites in two patients. ${ }^{11}$ There were no important changes in plasma volume in the 48 hours after paracentesis, although there was a small but significant rise in serum creatinine concentration. Peripheral oedema may protect the intravascular space by allowing mobilisation of fluid from the periphery.

Simon et al examined the effect on central haemodynamics and renal function of removing large volumes of ascitic fluid. ${ }^{12}$ A single 4-15 litre paracentesis ( 8 litres in 10 patients) was performed in 13 patients (seven of whom had peripheral oedema) without replacement of albumin at a rate of 2 litres every 1.5 hours. There was a prompt and sustained increase in cardiac output with no change in mean arterial pressure. Central venous and pulmonary capillary wedge pressure fell 